Combat Reporter 
This page intentionally left blank 


\title{
Combat Reporter
}

\author{
DON WHITEHEAD'S \\ WORLD WAR II DIARY AND MEMOIRS
}

Edited by John B. Romeiser 


\section{Copyright (C) 2006 Fordham University Press}

All rights reserved. No part of this publication may be reproduced, stored in a retrieval system, or transmitted in any form or by any means-electronic, mechanical, photocopy, recording, or any other- except for brief quotations in printed reviews, without the prior permission of the publisher.

World War II: The Global, Human, and Ethical Dimension

$$
\text { ISSN I54I-0293 }
$$

Library of Congress Cataloging-in-Publication Data

Whitehead, Don, 1908-

Combat reporter : Don Whitehead's World War II diary and memoirs / edited by

John B. Romeiser.-Ist ed.

p. cm.- (World War II-the global, human, and ethical dimension; I2)

Includes bibliographical references and index.

ISBN-I3: 978-0-8232-2675-7

ISBN-I0: 0-8232-2675-1

I. Whitehead, Don, 1908- 2. World War, 1939-1945-Campaigns-Africa, North

3. World War, 1939-1945-Campaigns-Italy-Sicily. 4. World War, I939-1945-

Journalists-Diaries. 5. World War, I939-I945-Personal narratives, American

6. War correspondents—United States—Diaries. I. Romeiser, John Beals, 1948- II. Title.

$$
\begin{gathered}
\mathrm{D}_{766.82 .} \mathrm{W}_{48} 2006 \\
940.54^{\prime} 1373092-\mathrm{dc22} \\
2006021330
\end{gathered}
$$

Printed in the United States of America

$080706 \quad 543321$

First edition 